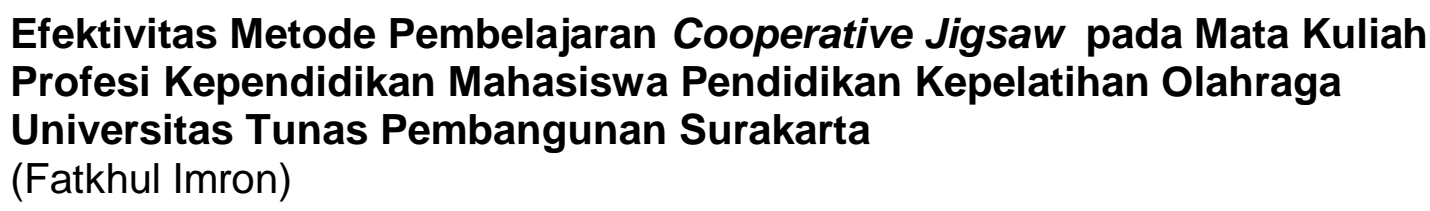

EFEKTIVITAS METODE PEMBELAJARAN COOPERATIVE JIGSAW PADA

MATA KULIAH PROFESI KEPENDIDIKAN MAHASISWA PENDIDIKAN

KEPELATIHAN OLAHRAGA UNIVERSITAS TUNAS PEMBANGUNAN

SURAKARTA 2020

\author{
Fatkhul Imron \\ PKO FKIP UTP Surakarta \\ fatkhul.imron@lecturer.utp.ac.id
}

\begin{abstract}
ABSTRAK
Tujuan dalam penelitian ini adalah untuk mengetahui : (1) Hasil belajar mata kuliah Profesi Kependidikan dengan metode pembelajaran Jigsaw pada mahasiswa PKO FKIP UTP Surakarta, dan (2) Efektivitas penggunaan metode pembelajaran tipe Jigsaw terhadap peningkatan hasil belajar mata kuliah Profesi Kependidikan pada mahasiswa PKO FKIP UTP Surakarta.

Penelitian ini merupakan penelitian kuantitatif dengan menggunakan pendekatan eksperimen semu (quasi eksperiment). Populasi dalam penelitian ini adalah mahasiswa PKO FKIP UTP Surakarta semester IV tahun akademik 2019/2020. Pengambilan sampel dilakukan dengan cara simple random sampling. Sebagai kelompok eksperimen adalah kelas IV B 33mahasiswa dan kelompok kontrol adalah kelas IV C 33 mahasiswa. Teknik pengumpulan data menggunakan metode tes dan dokumentasi. Teknik analisis data menggunakan uji analisis deskriptif dan uji prasyarat analisis data.

Hasil dari penelitian ini adalah : (1) Hasil belajar pada mata kuliah Profesi Kependidikan menggunakan metode Jigsaw lebih baik daripada metode konvensional, dan (2) analisis hasil belajar mahasiswa dalam mata kuliah Profesi Kependidikan menunjukkan mean skor pretest 61,55 dan postest 81,21 . Selain itu juga dapat dilihat dari hasil uji-t paired sample test nilai sig(2-tailed) $0,00<0,05$ hal tersebut menunjukkan bahwa perlakuan model pembelajaran JIGSAW lebih efektif dibandingkan dengan mahasiswa yang tidak mendapat perlakuan, atau diajar menggunakan metode konvensional.
\end{abstract}

Kata kunci : Model Pembelajaran Jigsaw, Profesi Kependidikan

\title{
PENDAHULUAN
}

Dalam rangka meningkatkan kualitas pendidikan tersebut tentu saja tidak terlepas dari proses belajar mengajar. Proses belajar mengajar pada hakikatnya adalah proses komunikasi yang di dalamnya terdapat berbagai kegiatan, dimana salah satu diantaranya adalah penyampaian materi pelajaran. Dosen sebagai penyelenggara kegiatan belajar harus dapat mengoptimalkan kegiatan belajar. Kemampuan dosen dalam menyampaikan materi memiliki andil yang besar dalam mencapai tujuan pendidikan yang telah ditetapkan. Akan tetapi dalam 


\section{Efektivitas Metode Pembelajaran Cooperative Jigsaw pada Mata Kuliah \\ Profesi Kependidikan Mahasiswa Pendidikan Kepelatihan Olahraga \\ Universitas Tunas Pembangunan Surakarta}

(Fatkhul Imron)

fungsinya tersebut, banyak dosen yang belum mengoptimalkan metode pembelajaran yang tepat dalam menyampaikan pembelajaran di kelas. Dengan adanya metode pembelajaran tentunya proses belajar mengajar lebih efektif. Pembelajaran yang efektif akan melatih dan menanamkan sikap demokratis bagi siswa serta menekankan siswa mampu belajar dengan cara belajarnya sendiri. Melalui metode pembelajaran aktivitas belajar mengajar menjadi menyenangkan dan mencapai efektivitas.

Pendidikan Kepelatihan Olahraga mewajibkan mahasiswanya mengambil mata kuliah profesi kependidikan yang bertujuan untuk mengasah kemampuan mahasiswa dalam mengajar secara profesional. Kompetensi dalam konteks pengembangan kurikulum adalah perpaduan dari pengetahuan, ketrampilan, nilai, dan sikap yang direfleksikan dalam kebiasaan berfikir dan bertindak. Demikian halnya di Universitas Tunas Pembangunan Surakarta, di perguruan tinggi ini semua program keahlian yang diajarkan guna membekali bagi mahasiswa yang ingin memasuki dunia kerja setelah lulus nanti.

Permasalahan yang ada dalam yang ada dalam dunia pendidikan formal senantiasa bertambah dari tahun ke tahun dan pendidikan dituntut selalu mengalami kemajuan dari berbagai segi. Salah satu segi penting dalam hal ini adalah proses belajar mengajar. Di dalam proses belajar mengajar ini terdapat berbagai macam kegiatan diantaranya adalah metode cara penyampaian pelajaran. Kebanyakan dari proses belajar mengajar khususnya penyampaian pelajaran teori Profesi Kependidikan di Universitas Tunas Pembangunan Surakarta menggunakan metode pembelajaran ceramah, sehingga mahasiswa hanya mendengarkan dosen menerangkan materi dan mahasiswa tidak ikut aktif dalam proses pembelajaran. Kelemahan dari pembelajaran metode ceramah ini adalah mahasiswa cenderung pasif. Hasil belajar mahasiswa pada mata kuliah Proesi Kependidikan $47 \%$ belum sepenuhnya mencapai nilai Kriteria Ketuntasan yang diharapkan, sehingga perlu mengadakan remidi untuk memenuhi nilai kriteria ketuntasan.

Untuk mengatasi kelemahan metode pembelajaran ceramah, dapat dilakukan dengan banyak pendekatan pembelajaran, salah satunya pembelajaran aktif, yaitu model pembelajaran kooperatif. Cooperative Learning, pada dasarnya suatu metode aktif yaitu melalui kerja sama yang dapat mempertinggi keterlibatan peserta didik, dengan melakukan aktivitasnya sendirisendiri. Metode pembelajaran ini akan menciptakan lebih banyak ide-ide yang dapat siswa pelajari yang akhirnya pengetahuan siswa menjadi tinggi dibandingkan dengan mendengarkan saja.

Jurnal IImiah SPIRIT, ISSN; 1411-8319 Vol. 20 No. 2 Tahun 2020 


\section{Efektivitas Metode Pembelajaran Cooperative Jigsaw pada Mata Kuliah \\ Profesi Kependidikan Mahasiswa Pendidikan Kepelatihan Olahraga \\ Universitas Tunas Pembangunan Surakarta \\ (Fatkhul Imron)}

Metode "Jigsaw" metode ini dikembangkan oleh Slavin. Jigsaw yaitu salah satu metode pembelajaran kooperatif. Dalam metode Jigsaw ada hubungan saling ketergantungan positif antar siswa, ada tanggung jawab perseorangan, serta ada komunikasi antar anggota kelompok. Siswa secara kolaboratif dalam kelompok untuk mencapai tujuan bersama ini memungkinkan metode Jigsaw dapat meningkatkan hasil belajar siswa. Metode pembelajaran kooperatif dimana siswa belajar dalam kelompok kecil yang terdiri dari 4-6 siswa/ mahasiswa secara heterogen. Selain itu berdasarkan observasi, metode pembelajaran kooperatif tipe Jigsaw belum digunakan pada pembelajaran profesi kependidikan di Pendidikan Kepelatihan Olahraga.

Berdasarkan latar belakang masalah yang dikemukakan di atas maka rumusan masalah dapat dirumuskan sebagai berikut: (1) Bagaimana hasil belajar mata kuliah Profesi Kependidikan dengan metode pembelajaran tipe Jigsaw pada mahasiswa PKO FKIP UTP Surakarta?, dan (2) Bagaimana perbedaan dan efektivitas penggunaan metode pembelajaran konvensional dan metode pembelajaran tipe Jigsaw terhadap peningkatan hasil belajar mata kuliah Profesi Kependidikan pada mahasiswa PKO FKIP UTP Surakarta?.

\section{TINJAUAN PUSTAKA}

\section{Pembelajaran}

Pembelajaran dari kata belajar, pengertian belajar adalah berubah, maksudnya belajar berarti usaha mengubah tingkah laku. A. Suhaenah Suparno (2001:1) mengartikan belajar sebagai suatu aktivitas yang menimbulkan perilaku yang relatif permanen akibat dari upayaupaya yang dilakukan. Dibawah ini adalah beberapa contoh metode pembelajaran yang sering digunakan oleh dosen yaitu:

\section{Pembelajaran Ceramah}

Menurut Jamal Ma'mur Asmani (2011:32) Pembelajaran ceramah adalah metode yang boleh dikatakan sebagai metode tradisional. Dalam penelitian ini yang dimaksud metode ceramah adalah pembelajaran yang lazim diterapkan dalam pembelajaran seharihari yang cenderung pada belajar hafalan dan jarang melibatkan peran aktif mahasiswa dalam pembelajaran di kelas.

\section{Pembelajaran Kooperatif}

Pembelajaran kooperatif merupakan strategi pembelajaran berdasarkan pada naluri

untuk bekerja sama. Krismanto (2000: 16) mengemukakan bahwa pada kegiatan Jurnal IImiah SPIRIT, ISSN; 1411-8319 Vol. 20 No. 2 Tahun 2020 


\section{Efektivitas Metode Pembelajaran Cooperative Jigsaw pada Mata Kuliah Profesi Kependidikan Mahasiswa Pendidikan Kepelatihan Olahraga Universitas Tunas Pembangunan Surakarta (Fatkhul Imron)}

pembelajaran kooperatif, sekelompok mahasiswa belajar dengan porsi utamanya mendiskusikan tugas-tugas persiapan pengolahan, dalam arti saling membantu menyelesaikan tugas atau memecahkan masalah dalam kelompoknya.

Dari beberapa definisi di atas dapat disimpulkan bahwa definisi pembelajaran adalah proses interaksi yang ditujukan untuk melakukan perubahan sikap dan pola pikir siswa menuju kearah yang lebih baik lagi untuk mencapai hasil belajar yang optimal.

\section{Metode Pembelajaran}

Menurut Nana Sudjana (2010:77-89) metode pembelajaran yang sampai saat ini masih banyak digunakan dalam proses pembelajaran, sebagai berikut : (a) ceramah, (b) tanya jawab, (c) diskusi, dan (d) Jigsaw. Didalam pendekaatan pembelajaran kooperatif terdapat metode pembelajaran Tipe Jigsaw. Pembelajaran dengan jigsaw dikembangkan oleh Elliot Aronson dan rekan-rekannya (Slavin, 2010:236). Menurut Slavin (2010:237) kunci metode jigsaw ini adalah interdependensi : tiap siswa bergantung kepada satu timnya untuk dapat memberikan informasi yang diperlukan supaya dapat berkinerja baik pada saat penilaian.

\section{Pembelajaran Kooperatif Tipe Jigsaw}

Pembelajaran dengan jigsaw dikembangkan oleh Elliot Aronson dan rekan-rekannya (Slavin, 2010:236). Menurut Slavin (2010:237) kunci metode jigsaw ini adalah interdependensi : tiap siswa bergantung kepada satu timnya untuk dapat memberikan informasi yang diperlukan supaya dapat berkinerja baik pada saat penilaian. Menurut Agus Suprijono (2009:89) pembelajaran jigsaw merupakan pembelajaran kooperatif dimana guru membagi kelas menjadi kelompok-kelompok lebih kecil. Jumlah kelompok bergantung pada konsep yang terdapat pada topic yang dipelajari. Jika satu kelas ada 40 siswa, maka setiap kelompok beranggotakan 10 orang. Keempat kelompok itu disebut kelompok asal, setelah kelompok asal terbentuk, guru membagikan materi tekstual kepada tiap-tiap kelompok. Berikutnya membentuk kelompok ahli, berikan kesempatan untuk berdiskusi. Setelah itu kembali pada kelompok asal dan menjelaskan hasil diskusi kepada kelompok masing-masing.

\section{Hasil Belajar Profesi Kependidikan}

Hasil belajar mahasiswa dipengaruhi oleh banyak faktor baik yang berasal dari dalam maupun dari luar. Adapun faktor-faktor yang mempengaruhi hasil belajar menurut Arikunto (1990 :21) adalah sebagai berikut: 


\section{Efektivitas Metode Pembelajaran Cooperative Jigsaw pada Mata Kuliah \\ Profesi Kependidikan Mahasiswa Pendidikan Kepelatihan Olahraga \\ Universitas Tunas Pembangunan Surakarta}

(Fatkhul Imron)

1. Faktor internal yaitu faktor yang bersumber dari dalam diri siswa, terdiri dari : faktor biologis, seperti: usia, kematangan dan kesehatan dan faktor psikologis, seperti : kelelahan, suasana hati, motivasi, minat dan kebiasaan belajar.

2. Faktor eksternal yaitu yang bersumber dari luar diri siswa, terdiri dari : faktor manusia, baik dalam keluarga, sekolah maupun masyarakat dan faktor non manusia, seperti : alam, lingkungan fisik dan fasilitas belajar.

Salah satu diantara mata kuliah yang diajarkan di Pendidikan Kepelatihan Olahraga Universitas Tunas pembangunan Surakarta adalah Profesi Kependidikan. Profesi kependidikan diajarkan sebagai mata kuliah wajib kependidikan untuk membekali mahasiswa sebagai calon pendidik. Dalam mata kuliah ini mahasiswa diberikan materi mulai dari hakikat profesi guru, administrasi profesi guru, supervisi pendidikan, dan organisasi profesi guru. Sebagai mata kuliah wajib mahasiswa yang mengambil mata kuliah profesi kependidikan ditargetkan menguasai materi dengan indikator nilai mata kuliah yang baik. Dalam rangka pencapaian tersebut maka mata kuliah profesi kependidikan harus disajikan dengan metode yang sesuai dan dapat meningkatkan hasil belajar mahasiswa yang mengikutinya, salah satunya dosen menerapkan metode pembelajaran kooperatif tipe JIGSAW.

\section{METODE PENELITIAN}

Penelitian ini merupakan penelitian kuantitatif dengan menggunakan pendekatan eksperimen semu (quasi eksperiment). Eksperimen semu adalah jenis komparasi yang membandingkan pengaruh pemberian suatu perlakuan (treatment) pada suatu objek (kelas eksperimen) serta melihat besar pengaruh perlakuannya. Dalam penelitian ini terdapat dua kelompok, yaitu kelompok eksperimen dan kelompok kontrol. Kelompok eksperimen merupakan kelompok yang diberikan perlakuan atau treatment, sedangkan pada kelompok kontrol tidak diberikan perlakuan. Perlakuan atau treatment yang dimaksud dalam penelitian ini adalah penggunaan metode pembelajaran kooperatif tipe Jigsaw dalam pembelajaran. Sedangkan desain penelitian menggunakan control group pre-test post-test design (Suharsimi Arikunto, 2006 : 77).

Penelitian ini dilaksanakan di kelas mata kuliah Profesi Kependidikan PKO FKIP UTP secara daring karena penelitian dilaksanakan pada saat terjadinya wabah Covid 19. Penelitian ini dilaksanakan pada bulan April sampai Juli 2020. 


\section{Efektivitas Metode Pembelajaran Cooperative Jigsaw pada Mata Kuliah \\ Profesi Kependidikan Mahasiswa Pendidikan Kepelatihan Olahraga \\ Universitas Tunas Pembangunan Surakarta \\ (Fatkhul Imron)}

Pada penelitian ini populasinya adalah mahasiswa PKO FKIP UTP Surakarta semester IV tahun akademik 2019/2020. Endang Mulyatiningsih (2011: 10) mengemukakan bahwa populasi adalah sekumpulan orang, hewan, tumbuhan, atau benda yang mempunyai karakteristik tertentu yang akan diteliti. Sedangkan sampel penelitian terdiri dari kelompok eksperimen kelas IV B 33 mahasiswa dan kelompok kontrol kelas IV C 33 mahasiswa.

Untuk teknik pengumpulan data menggunakan tes dan non tes (dokumentasi). Metode tes dipergunakan untuk mengukur hasil belajar mahasiswa, dengan menggunakan model pembelajaran kooperatif Jigsaw. Sedangkan metode dokumentasi dipergunakan untuk mendapatkan data mengenai jumlah dan nama siswa yang dijadikan sampel penelitian pada masing-masing kelompok.

Teknik analisis data ada dua macam, yaitu uji persyaratan analisis data dan teknik pengujian hipotesis menggunakan uji-t melalui SPSS 17. Sebelum pengujian hipotesis, akan dilakukan analisis deskriptif dan uji persyaratan analisis yaitu uji normalitas sebaran data masing-masing variabel. Uji normalitas dengan menggunakan uji Kolmogorov-Smirnov, Uji homogenitas dengan menggunakan uji-f. Setelah seluruh data memenuhi persyaratan dari uji normalitas dan uji homogenitas maka dilanjutkan dengan pengujian hipotesis dengan uji $-\mathrm{t}$.

\section{HASIL PENELITIAN DAN PEMBAHASAN}

\section{Analisis Statistik Deskriptif}

Penelitian eksperimen ini berlangsung dari bulan April hingga Juni 2020. Dalam penelitian ini data diambil dengan menggunakan metode tes yang dilakukan sebanyak dua kali terhadap kelompok eksperimen mahasiswa semester IV Pendidikan Kepelatihan Olahraga tahun akademik 2019/2020.

Kelompok eksperimen yaitu mahasiswa kelas B PKO FKIP UTP sebanyak 33 mahasiswa yang diberi perlakuan dengan menggunakan metode pembelajaran tipe Jigsaw dan pada kelompok kontrol yaitu mahasiswa kelas C PKO FKIP UTP sebanyak 33 mahasiswa yang tidak diberi perlakuan atau hanya menggunakan metode konvensional. Setelah hasil penilaian terkumpul, kemudian data dianalisis dengan statistik deskriptif dan uji-t.

\section{a. Analisis Perbandingan Nilai Hasil Belajar Pada Mata Kuliah Profesi}

\section{Kependidikan}

Jurnal IImiah SPIRIT, ISSN; 1411-8319 Vol. 20 No. 2 Tahun 2020 


\section{Efektivitas Metode Pembelajaran Cooperative Jigsaw pada Mata Kuliah \\ Profesi Kependidikan Mahasiswa Pendidikan Kepelatihan Olahraga \\ Universitas Tunas Pembangunan Surakarta}

(Fatkhul Imron)

Dari hasil analisis data posttest hasil belajar mahasiswa siswa yang telah dieksperimenkan dengan mengklasifikasikan pada kriteria ketuntasan atau norma penilaian, maka dapat diketahui bahwa pada mahasiswa yang dieksperimenkan memenuhi kriteria ketuntasan hasil belajar sebanyak 19 mahasiswa (58\%), dan yang memenuhi ketuntasan sebanyak 14 mahasiswa (42\%).

b. Uji T (t - test) untuk Hasil Perbedaan Post Test dan Pre Test

Setelah diperoleh data melalui test sebelum perlakuan (pre-test) dan tes setelah perlakuan (post-test) maka diperoleh hasil untuk dianalisis menggunakan uji-t. Adapun hasil perbedaan nilai post test dan pre test dapat dilihat pada tabel dibawah ini.

Tabel 1. Hasil analisis pretest dan postest subjek penelitian

Paired Samples Statistics

\begin{tabular}{|r|r|r|r|r|}
\hline & \multicolumn{1}{|c|}{ Mean } & $\mathrm{N}$ & Std. Deviation & Std. Error Mean \\
\hline Pair 1 pre_ke & 61.55 & 33 & 3.598 & .626 \\
& & & & .564 \\
\hline
\end{tabular}

Paired Samples Correlations

\begin{tabular}{|l|r|r|r|}
\hline & $\mathrm{N}$ & Correlation & \multicolumn{1}{c|}{ Sig. } \\
\hline Pair 1 pre_ke \& post_ke & 33 & .577 & .000 \\
\hline
\end{tabular}

Paired Samples Test

\begin{tabular}{|l|r|r|r|r|r|}
\hline \multirow{2}{*}{} & \multicolumn{5}{|c|}{ Paired Differences } \\
\cline { 2 - 6 } & \multicolumn{3}{|c|}{} & \multicolumn{2}{|c|}{$95 \%$ Confidence Interval of the } \\
Difference
\end{tabular}

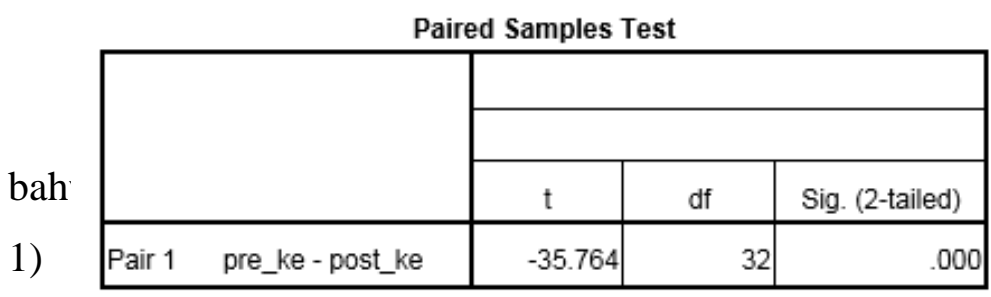

thui

ttest

81,21 sedangkan N masing-masing 33 mahasiswa. Sedangkan standar deviasi untuk pretest 3,598 dan postest 3,238. Mean standar error untuk pretest 0,626 dan posttest 0,564 . 


\section{Efektivitas Metode Pembelajaran Cooperative Jigsaw pada Mata Kuliah \\ Profesi Kependidikan Mahasiswa Pendidikan Kepelatihan Olahraga \\ Universitas Tunas Pembangunan Surakarta}

(Fatkhul Imron)

2) Out put Paired Samples Correlation menampilkan besarnya korelasi antara pretest dan postest dimana terlihat angka korelasi keduanya sebesar 0,577 dan angka signifikansi 0,00. Pengambilan keputusan didasarkan pada hasil probabilitas yang diperoleh yaitu :

Berdasarkan hasil tersebut menunjukkan bahwa antara tes awal dan tes akhir pada subjek penelitian terdapat perbedaan yang signifikan.

3) Out put Paired Samples Test menampilkan hasil analisis perbandingan dengan menggunakan uji tes t. Out put menampilkan mean pretest dan postest sebesar -19,667. Standar deviasinya 3,159, mean standar errornya 0,550. Perbedaan terendah keduanya sebesar $-20,787$ sementara perbedaan tertinggi $-18,547$. Hasil uji tes $t=-35,764$ dengan df = 32 dan signifikansi 0,00. Dengan demikian dapat diinterprestasikan sebagai berikut:

a) Dengan berpedoman pada nilai uji tes $t$ dengan membandingkan $t$ hitung dengan $t$ tabel yaitu dengan $\mathrm{df}=32$ diperoleh angka 2,042 dengan taraf signifikansi $5 \%$. Hasil t hitung $=-35,764$ berarti lebih besar dari t tabel (dalam hal ini tanda minus diabaikan). Dengan demikian t hitung > dari t tabel yang berarti Ho ditolak.

b) Dengan berpedoman pada besarnya angka signifikansi, maka keputusan diambil dengan ketentuan :

- Jika nilai probabilitas > 0,05 maka Ho diterima

- Jika nilai probabilitas < 0,05 maka Ho ditolak

Kriteria pengujian

- Ho = tidak ada perbedaan yang signifikan

- $\mathrm{H}_{\mathrm{I}}=$ ada perbedaan yang signifikan

Hasil perhitungan diatas menunjukkan bahwa nilai signifikansi $0,00<0,05$, dan hal tersebut menunjukkan bahwa Ho ditolak. Berdasarkan hasil tersebut menunjukkan, antara tes awal dan tes akhir pada kelompok eksperimen terdapat perbedaan yang signifikan.

Keefektifan penerapan model pembelajaran jigsaw seperti ditunjukkan oleh hasilhasil analisis data bahwa:

1. Hasil pembelajaran pada mata kuliah Profesi Kependidikan menggunakan metode Jigsaw lebih baik daripada metode konvensional. Hal ini diperkuat dengan adanya analisis data terhadap kegiatan siswa dalam pembelajaran selama 4 kali pertemuan secara daring adalah efektif, karena setiap aspek yang diamati sebagian besar berada pada kategori baik dan sebagian baik sekali. 


\section{Efektivitas Metode Pembelajaran Cooperative Jigsaw pada Mata Kuliah \\ Profesi Kependidikan Mahasiswa Pendidikan Kepelatihan Olahraga \\ Universitas Tunas Pembangunan Surakarta \\ (Fatkhul Imron)}

2. Dari analisis hasil belajar mahasiswa dalam mata kuliah Profesi Kependidikan menunjukkan bahwa perlakuan model pembelajaran JIGSAW lebih efektif dibandingkan dengan mahasiswa yang tidak mendapat perlakuan, atau diajar menggunakan metode konvensional. Dari segi hasil akhir menunjukkan bahwa, dari uji hipotesis penelitian ini teruji bahwa metode pembelajaran JIGSAW berpengaruh terhadap peningkatan hasil belajar mahasiswa. Oleh karena itu dapat disimpulkan bahwa ada perbedaan hasil belajar mahasiswa semester IV pada mata kuliah Profesi Kependidikan sebelum diberi perlakuan dengan setelah diberi perlakuan metode pembelajaran JIGSAW.

\section{SIMPULAN}

Berdasarkan hasil penelitian dan pembahasan pembelajaran mata kuliah profesi kependidikan mahasiswa semester IV PKO FKIP UTP tahun akademik 2019/2020 dapat diambil kesimpulan sebagai berikut :

a. Hasil belajar pada mata kuliah Profesi Kependidikan menggunakan model Jigsaw lebih baik daripada metode konvensional.

b. Dari analisis hasil belajar mahasiswa dalam mata kuliah Profesi Kependidikan menunjukkan mean skor pretest 61,55 dan postest 81,21 . Selain itu juga dapat dilihat dari hasil uji-t paired sample test nilai sig(2-tailed) $0,00<0,05$ hal tersebut menunjukkan bahwa perlakuan model pembelajaran JIGSAW lebih efektif dibandingkan dengan mahasiswa yang tidak mendapat perlakuan, atau diajar menggunakan metode konvensional.

\section{DAFTAR PUSTAKA}

Agus Suprijono. (2009). Cooperative Learning Teori dan Aplikasi Paikem. Yogyakarta: Pustaka Pelajar

A.Suhaenah Suparno. (2001). Membangun Kompetensi Belajar. Direktorat Jendral Pendidikan Tinggi Departemen Pendidikan Nasional.

Endang Mulyatiningsih. (2011). Riset Terapan Bidang Pendidikan dan Teknik. Yogyakarta. UNY Press.

Jamal Ma'mur Asmani. (2011). Tips Amplikasi Paikem. Yogyakarta : Diva Press 
Efektivitas Metode Pembelajaran Cooperative Jigsaw pada Mata Kuliah

Profesi Kependidikan Mahasiswa Pendidikan Kepelatihan Olahraga

Universitas Tunas Pembangunan Surakarta

(Fatkhul Imron)

Krismanto, A. (2000). Belajar Secara Kooperatif Sebagai Salah Satu Pembelajaran Aktif. Yogyakarta: PPPG Matematika.

Nana Sudjana. (1999). Penilaian Hasil Proses Belajar Mengajar. Bandung : PT. Remaja Roesdakarya.

Slavin. (2010). Cooperative Learning (Teori, Riset, dan Praktek). Bandung: Nusa Media.

Suharsimi Arikunto. (2002). Dasar-Dasar Evaluasi Pendidikan. Jakarta: Rineka Cipta. 